\title{
PENGEMBANGAN MODUL IPA TERPADU BERBASIS INKUIRI TERBIMBING UNTUK MENINGKATKAN KETERAMPILAN PROSES SAINS, MINAT, DAN HASIL BELAJAR SISWA PADA MATERI FOTOSINTESIS DI KELAS VIII SMP NEGERI 9 JAYAPURA
}

\author{
Simon Kalemben ${ }^{1)}$, Basa T. Rumahorbo ${ }^{2)}$, dan Johnson Siallagan ${ }^{3)}$ \\ ${ }^{1)}$ SMP Negeri 9 Jayapura \\ ${ }^{2)}$ Program studi Magister Pendidikan IPA UNCEN \\ ${ }^{3)}$ Program studi Magister Pendidikan IPA UNCEN
}

\begin{abstract}
.
This research is a research and development that aims to know to create an integrated IPA module, the feasibility of integrated IPA module, the improvement of science process skill, the interest and student's learning process by using integrated IPA module, the advantages and disadvantages using integrated IPA module. This research conducted in class VIII A of SMP Negeri 9 Jayapura with 40 students. The result shows that : 1) The improvement of integrated IPA module based on inquiry on photosynthesis material is started with defining phase, module planning, draft module design, and development 2) The feasibility of integrated IPA module from validator $99.40 \%$ with very decent category, IPA teachers got $90 \%$ with very good category, and the result of try out in small scale got $84.16 \%$ 3) The improvement of students process skill by using integrated IPA module got $78.68 \%$ with skilled category 4) The improvement of students interest in using got $96.25 \%$ with very high category 5) The improvement of student learning result students got average 46 in average pretest, and it increase be 70.50 in posttest and n- Gain got 0.45 with middle category 6) Integrated IPA module can improve the process skill, students interest and learning result.
\end{abstract}

Key words: Module, Integrated Science, Guided Inquiry, Science Processs skills, Interests, Learning Outcomes .

PENDAHULUAN

Pembelajaran IPA Terpadu merupakan pembelajaran ilmu pengetahuan alam dengan memadukan beberapa pokok bahasan dari berbagai bidang kajian fisika, biologi, dan kimia menjadi satu bahasan. Melalui pembelajaran IPA terpadu, siswa dapat mempelajari tentang alam beserta fenomena yang terjadi di dalamnya secara utuh, dengan demikian siswa aktif mencari, menggali, dan menemukan konsep IPA dalam kehidupan. Model pembelajaran IPA Terpadu di kelas sejauh ini belum diajarkan secara terpadu . masih cenderung berlangsung secara terpisah antara biologi, fisika, dan kimia. 
Hal tersebut disebabkan antara lain karena: (1) latar belakang pendidikan guru berasal dari bidang biologi, fisika, dan kimia sehingga perlu kerjasama antar guru; (2) belum ada bahan ajar IPA terpadu yang terintegrasi; (3) guru belum berani mencoba sesuatu yang berbeda dengan kebiasaan mengajar selama ini.

Berdasarkan pengalaman peneliti dan diskusi dengan guru mata pelajaran IPA yang ada di SMP Negeri 9 Jayapura, guru masih kesulitan dalam menyusun materi bahan ajar atau modul IPA Terpadu. Pengembangan Modul IPA Terpadu merupakan hal yang dan perlu dikembangkan untuk pembelajaran. Salah satu contoh materi fotosintesis merupakan salah satu materi IPA Terpadu yang cukup menantang dan menuntut siswa untuk dapat mengetahui konsep dan proses yang terjadi dalam fotosintesis. Proses pembelajaran materi fotosintesis selama ini masih dilakukan dengan metode ceramah disertai dengan tanya jawab dan hanya berpegang pada Lembar kerja siswa (LKS) yang berisi materi yang kurang lengkap dan tidak mengarahkan siswa untuk melakukan kegiatan atau eksperimen. Proses pembelajaran yang cenderung berpusat pada guru, menyebabkan siswa lebih banyak menerima informasi dari guru dan keterlibatan siswa dalam pembelajaran pasif sehingga proses pengembangan keterampilan proses siswa dan animosiswa belajar menjadi rendah. Salah satu alternatif untuk mengatasi permasalahan tersebut dengan cara membuat perangkat pembelajaran yang memuat materi IPA Terpadu dalam suatu modul.

Berdasarkan hasil penelitian yang dilakukan oleh Mularsih (2007) menyimpulkan bahwa pembelajaran yang menggunakan modul dengn pndekatan inkuiri terbimbing dapat meningkatkan ketrampilan proses dan menyebabkan siswa dapat belajar secara mandiri.

Proses pembelajaran dengan pendekatan inkuiri terbimbing, siswa diberikan kesempatan untuk menemukan sendiri cara untuk memecahkan suatu masalah. Guru berperan memfasilitasi siswa untuk terlibat aktif dalam kegiatan pembelajaran dengan memberikan petunjuk berupa pertanyaan-pertanyaan yang sifatnya membimbing siswa untuk menyelesaikan masalah (Depdiknas 2006)

Penelitian ini bertujuan untuk mengembangkan suatu modul pembelajaran IPA secara terpadu pada 
materi fotosintesis berbasis inkuiri terbimbing untuk meningkatkan keterampilan proses sains, minat, dan hasil belajar siswa pada materi fotosintesis dalam pembelajaran IPA di kelas VIII SMP Negeri 9 Jayapura.

\section{METODOLOGI PENELITIAN}

Metode dalam penelitian ini adalah penelitian dan pengembangan ( Research and Development / $R \& D)$, bertujuan untuk membuat suatu produk media pendidikan, yaitu modul IPA terpadu. Langkah penelitian pengembangan modul IPA Terpadu berbasis inkuiri terbimbing materi fotosintesis ditunjukkan pada gambar 1 berikut ini :

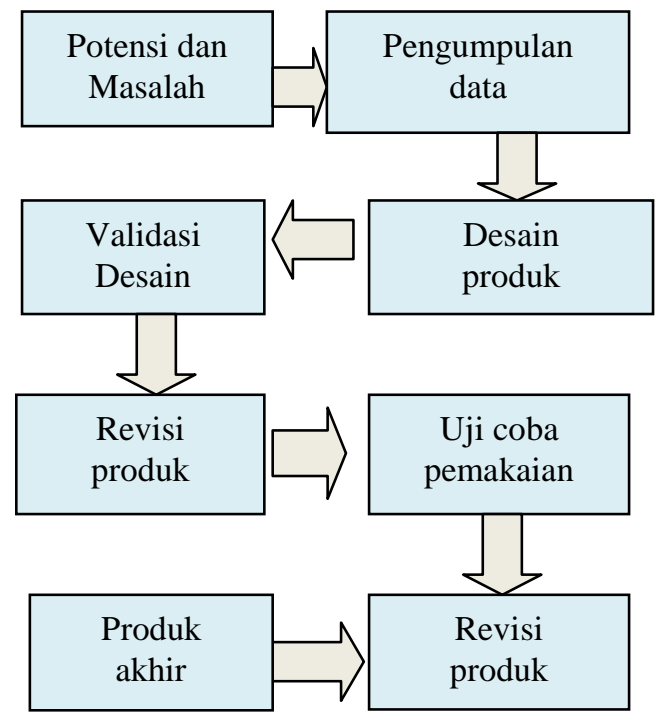

Gambar 1 Langkah-langkah Metode $R \& D$ (Sugiyono, 2016)

\section{Populasi dan Sampel Penelitian}

Populasi dalam penelitian ini adalah seluruh peserta didik kelas VIII SMP Negeri 9 Jayapura.

Sampel dalam penelitian ini adalah kelas VIII A dengan jumlah siswa sebanyak 40 orang.

Teknik pengambilan sampel penelitian ini adalah purposive sampling.

Prosedur Penelitian ditunjukan pada skema gambar 2 berikut :

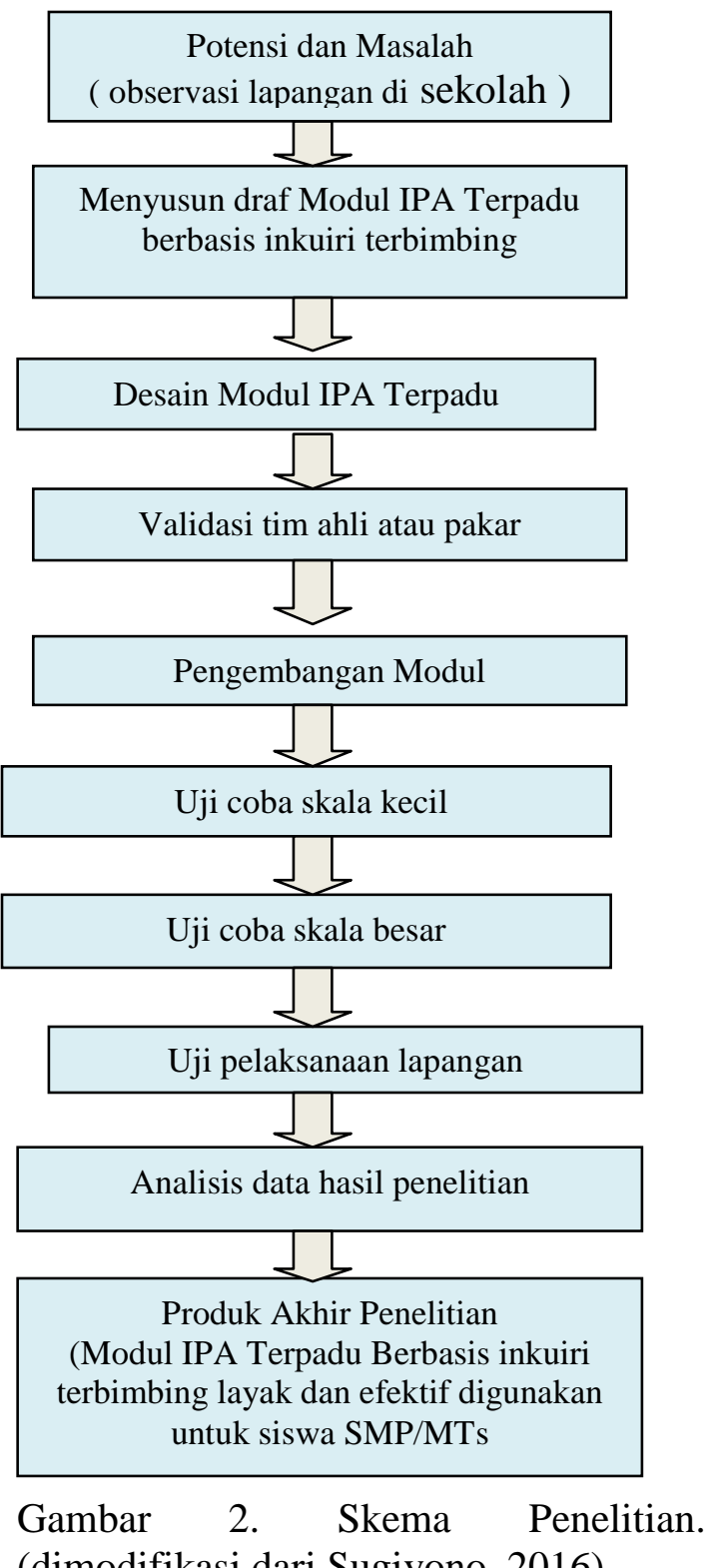

(dimodifikasi dari Sugiyono, 2016) 
Instrumen penelitian yang digunakan untuk mengumpulkan data dalam uji coba, sebagai berikut :

1. Angket/kuisioner

Kuisioner sebagai lembar penilaian produk digunakan untuk mendapatkan data tentang kelayakan modul hasil pengembangan

2. Angket respon peserta didik

Angket diberikan kepada 6 orang peserta didik untuk uji terbatas dan untuk uji skala luas angket diberikan kepada peserta didik dikelas sampel.

3.Tes hasil belajar

Instrument tes hasil belajar digunakan untuk mengukur hasil belajar peserta didik sebelum dan sesudah penerapan produk (Riduwan 2012)

Validasi modul dilakukan oleh tiga validator dengan memberikan penilaian terhadap setiap komponen dari aspek penilaian kelayakan isi, komponen kelayakan bahasa, dan komponen kelayakan penyajian.

\section{HASIL DAN PEMBAHASAN}

1. Pembuatan Modul IPA Terpadu Berbasis Inkuiri Terbimbing Pada Materi Fotosintesis Siswa Kelas VIII SMP Negeri 9 Jayapura

Pembuaantan modul IPA terpadu berbasisi inkuiri terbimbing pada materi fotosintesis dilakukan melalui tujuh tahapan. Tahap pertama diawali dengan mengidentifikasi potensi dan masalah meliputi analisis permasalahan, analisis peserta didik, analisis konsep dan analisis tujuan pembelajaran. Tahap kedua melakukan pengumpulan data sebagai bahan perencanaan modul. Tahap ketiga membuat desain modul IPA terpadu. Penyusunan modul IPA terpadu yang dilakukan dalam penelitian ini meliputi :1) Menetapkan bidang kajian IPA terpadu yang akan dipadukan., 2) Analisis kompetensi dasar. 3) Menentukan tema atau topik. Merumuskan indikator pencapaian kompetensi, 4) Merumuskan tujuan pembelajaran yang akan dicapai siswa, 5) Menentukan metode yang tepat., 6) Pembuatan desain halaman muka halaman kata pengantar dan daftar isi, 7) Pembuatan petunjuk penggunaan modul, 8) Penulisan bagian pendahuluan, 9) Penulisan bagian penyajian, 10) Penulisan bagian penutup dan 11) Penulisan glosarium dan daftar pustaka. Tahap keempat melakukan validasi desain modul. Tahap kelima melakukan revisi desain modul bila dianggap perlu. Tahap keenam melakukan uji coba skala kecil Subjek uji coba adalah siswa kelas 
VIII B. Kelompok kecil ini berjumlah 6 responden siswa yang dipilih secara acak dari kelas tersebut. Hasil tanggapan siswa pada skala kecil terhadap modul IPA terpadu yang dikembangkan mendapat presentase skor sebesar $84,16 \%$ dengan kriteria sangat baik dan terakhir Tahap ketujuh melakukan uji coba skala luas Uji coba skala luas dilaksanakan di kelas VIII A. Data yang diperoleh pada ujicoba skala luas adalah data keterampilan proses sains siswa, nilai pretest, nilai posttest, minat siswa, dan tanggapan guru mengenai pengembangan modul IPA berbasis inkuiri terbimbing materi fotosintesis yang menjadi subjek penelitian.

\section{Kelayakan Pengembangan Modul}

IPA Terpadu Berbasis Inkuiri Terbimbing Pada Materi Fotosintesis Kelas VIII SMP Negeri 9 Jayapura

Penilaian kelayakan modul IPA terpadu berbasis inkuiri terbimbing pada materi fotosintesis dilakukan dengan menggunakan angket yang diisi oleh 3 orang validator. Validator tersebut meliputi ahli materi, ahli pedagogik dan ahli bahasa.

Berdasarkan penilaian dari ketiga tim ahli sebagai validator, modul IPA terpadu berbasis inkuiri terbimbing mendapat penilaian presentase skor ratarata $99,40 \%$ dan dinyatakan layak digunakan tanpa revisi.

\section{Hasil Uji Coba Modul}

Pada uji coba skala kecil diperoleh presentase skor rata-rata $84,16 \%$ dengan kriteria sangat baik hasil uji coba skala luas modul IPA terpadu berbasis Inkuiri terbimbing yang dilakukan untuk mengetahui tanggapan guru IPA terhadap modul, peningkatan KPS, peningkatan minat belajar siswa, peningkatan hasil belajar pada materi fotosintesis.

$\begin{array}{lll}\text { a. Tanggapan Guru } & \text { Terhadap } & \text { Modul } \\ \text { IPA Terpadu } & \text { Berbasis } & \text { Inkuiri } \\ \text { Terbimbing } & \text { Pada } & \text { Materi } \\ \text { Fotosintesis. } & & \end{array}$

Berdasarkan hasil angket tanggapan guru terhadap modul IPA terpadu berbasis inkuiri terbimbing yang dikembangkan memperoleh hasil presentase rata-rata skor yang diperoleh 90 dengan kriteria sangat baik.

\section{b. Keterampilan Proses Sains Siswa Dengan Menggunakan Modul IPA Terpadu Berbasis Inkuiri Terbimbing Berdasarkan data yang diperoleh melalui pengamatan dan aporan praktikum, hasil analisis yang diperoleh yaitu :}


Hasil keseluruhan penilaian KPS dari RPP-1, sampai RPP-3 menunjukkan keterampilan proses sains yang diamati pada RPP-1 menghasilkan presentase skor rata-rata $77,76 \%$ kategori terampil, RPP-2 dengan presentase skor rata-rata 78,48\% kategori sangat terampil, dan RPP-3 dengan presentase skor rata-rata $79,91 \%$ terampil. Hasil pengamatan keterampilan proses sains secara klasikal menghasilkan presentase skor rata-rata 78,68\% kategori terampil. Rata-rata penilaian kategori KPS secara keseluruhan dari RPP-1 sampai RPP-3 diperoleh data $42,5 \%$ siswa sangat terampil, $63,3 \%$ siswa terampil dan 17,5 $\%$ siswa kurang terampil.

Hasil rekapitulasi observasi komponen KPS RPP-1 sampai RPP-3 memperlihatkan bahwa terdapat peningkatan presentase KPS rata-rata pada setiap pertemuan meskipun presentasenya kecil yaitu dari RPP-1 ke RPP-2 meningkat 0,72\%, RPP-2 ke RPP-3 meningkat $1,43 \%$. Hal ini terjadi karena siswa sudah mulai terbiasa menerapkan keterampilan proses yang mereka miliki dalam aktivitas pembelajaran sehingga kemampuan kerja ilmiahnya meningkat dalam setiap pertemuan
Hasil presentase KPS rata-rata yang diperoleh sebesar 76,68\%. Berdasarkan hasil tersebut dapat disimpulkan bahwa modul IPA terpadu berbasis inkuiri terbimbing materi fotosintesis dapat meningkatkan keterampilan proses sains siswa kelas VIII SMP Negeri 9 Jayapura.

\section{Minat Belajar Siswa Dengan Menggunakan Modul IPA Terpadu Berbasis Inkuiri Terbimbing}

Berdasarkan hasil angket minat belajar siswa memperlihatkan bahwa presentase siswa yang memberikan tanggapan positip sebesar 96,25 kriteria sangat tinggi.. Berdasarkan hasil tersebut dapat disimpulkan bahwa minat belajar peserta didik terhadap pembelajaran IPA dengan menggunakan modul sangat baik, artinya dapat meningkatkan minat belajar siswa. Penilaian minat belajar siswa menggunakan instrumen berupa angket yang diberikan setelah pembelajaran RPP Ke-3 berlangsung.

Data analisis diketahui $96 \%$ siswa memberi tanggapan positip yang berarti bahwa minat belajar siswa dalam pembelajaran IPA dengan menggunakan modul IPA terpadu berbasis inkurir terbimbing materi fotosintesis termasuk kriteria sangat tinggi 
Presentase minat belajar siswa terhadap modul IPA disajikan pada gambar 3 berikut ini:

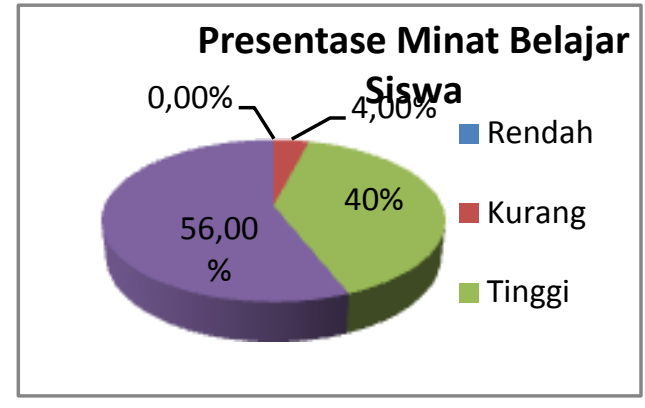

Gambar 3 Diagram presentase minat belajar siswa terhadap modul IPA terpadu

$$
\text { Berdasarkan gambar } 3
$$
menunjukkan bahwa minat belajar siswa kategori sangat tinggi mengalami peningkatan sebesar 56\%, kategori tinggi mengalami peningkatan sebesar $13,70 \%$, kategori kurang sebesar $51,5 \%$ dan kategori rendah sebesar 18,20\%.

\section{Hasil Belajar Siswa Dengan Menggunakan Modul IPA Terpadu Berbasis Inkuiri Terbimbing}

Hasil belajar RPP 1 sampai dengan RPP 3 diperoleh nilai pretest rata-rata 46,25 nilai posttest rata-rata 70,25 berarti ada peningkatan sebesar 24,00. Hasil uji nGain diperoleh $n$-Gain rata-rata sebesar 0,45 maka penguasaan konsep siswa termasuk dalam kategori sedang. Nilai rata-rata posttest yang diperoleh siswa pada RPP-1 sebesar 70,25, mengalami penurunan sebesar 0,25 pada pada RPP2 dengan nilai rata-rata posttest yang diperoleh siswa 70,00 Hal ini terjadi karena materi pembelajaran pada RPP-1 masih bersifat umum dan setelah masuk di RPP-2 dan RPP-3 materi pembelajaran sudah masuk pembuktian melalui praktikum. Nilai rata-rata posttest yang diperoleh siswa pada RPP2 mengalami peningkatan sebesar 0,50 pada RPP-3 dengan rata-rata nilai posttest sebesar 7,50. Hal ini terjadi karena siswa sudah mulai terbiasa melaksanakan aktivitas pembelajaran dengan praktikum dan sudah terbiasa mengerjakan soal pada RPP-2 sehingga ketika masuk aktivitas pembelajaran pada RPP-3 sudah kembali mengalami peningkatan meskipun presentasenya kecil.

Berdasarkan hasil analisis skor pretest dan posttest menunjukkan ratarata $n$-Gain RPP-1 sebesar 0,46 kategori sedang mengalami penurunan sebesar 0,04 pada RPP-2 dengan rata-rata $n$ Gain sebesar 0,42. Kemudian nilai $n$ Gain kembali mengalami peningkatan sebesar 0,04 pada RPP-3 dengan ratarata $n$-Gain sebesar 0,46 , termasuk dalam kategori sedang. Hal ini terjadi karena materi yang disajikan pada RPP-1 masih bersifat umum, dan ketika masuk 
ke RPP-2 materi yang disajikan harus melalui proses pembuktian, kemudian masuk ke RPP-3 siswa sudah mulai terbiasa melaksanakan aktivitas pembelajaran melalui proses pembuktian.

Hasil uji n-Gain yang diperoleh pada RPP-1 sampai RPP-3 dirataratakan sehingga diperoleh rata-rata $n$ Gain klasikal sebesar 0,45. Nilai ini sudah termasuk ke dalam batas kelayakan yang ditetapkan yaitu jika kriteria n-Gain secara klasikal sekurangkurangnya tergolong sedang sehingga modul IPA terpadu berbasis inkuiri terbimbing dikatakan dapat meningkatkan hasil belajar siswa.

\section{Kelebihan Dan Kekurangan}

Modul IPA Terpadu Berbasis

Inkuiri Terbimbing Pada Materi Fotosintesis Kelas VIII SMP Negeri 9 Jayapura

Kelebihan dari modul IPATerpadu yang dikembangkan adalah dapat meningkatkan keterampilan proses sains, minat dan hasil belajar siswa.

Kekurangan dari modul IPA Terpadu yang dikembangkan adalah Gambar yang sesuai dengan pendekatan kearifan lokal masih kurang.

\section{SIMPULAN DAN SARAN}

\section{A. SIMPULAN}

Berdasarkan hasil penelitian ini dapat disimpulkan:

1. Cara membuat modul IPA terpadu berbasis inkuiri terbimbing pada materi fotosintesis ditempuh melalui 7 tahapan, yaitu tahap pendefinisian, pengumpulan data untuk perencanaan modul, pembuatan desain modul, validasi desain modul, revisi desain modul, ujicoba skala kecil dan ujicoba skala luas.

2. Modul IPA terpadu berbasis inkuiri terbimbing pada materi fotosintesis layak untuk digunakan siswa kelas VIII SMP Negeri 9 Jayapura karena diperoleh kelayakan modul dari validator sebesar $99,40 \%$ dengan kategori sangat layak, guru IPA sebesar 90\% dengan kategori sangat baik, hasil ujicoba skala kecil $84,16 \%$.

3. Modul IPA terpadu berbasis inkuiri terbimbing pada materi fotosintesis dapat meningkatkan keterampilan proses sains siswa kelas VIII SMP Negeri 9 Jayapura sebesar 78,68\% kategori terampil.

4. Modul IPA terpadu berbasis inkuiri terbimbing pada materi fotosintesis dapat meningkatkan minat belajar siswa kelas VIII SMP Negeri 9 
Jayapura sebesar $96,25 \%$ dengan kategori sangat tinggi.

5. Modul IPA terpadu berbasis inkuiri terbimbing pada materi fotosintesis yang dikembangkan dapat meningkatkan hasil belajar siswa kelas VIII SMP Negeri 9 Jayapura dengan rata-rata nilai pretest 46 menjadi 70,50 pada posttest, dan uji $n$-Gain rata-rata 0,45 dengan kategori sedang.

6. Kelebihan dari modul IPA terpadu berbasis inkuiri terbimbing pada materi fotosintesis yang dikembangkan adalah dapat meningkatkan minat, keterampilan proses sains, dan hasil belajar siswa belajar siswa. Sedangkan yang menjadi kekurangan modul yang dikembangkan adalah kurangnya gambar yang sesuai dengan pendekatan kearifan lokal.

\section{B. SARAN}

Berdasarkan kesimpulan yang diperoleh dari penelitian ini, penulis menyarankan hal-hal sebagai berikut :

1. Modul IPA terpadu berbasis inkuiri terbimbing pada materi fotosintesis yang dikembangkan dapat digunakan untuk meningkatkan keterampilan proses sains, minat dan hasil belajar siswa. Modul ini dapat dikembangkan lebih lanjut khususnya guru IPA sebagai salah satu upaya untuk meningkatkan keterampilan proses sains, minat dan hasil belajar siswa.

2. Proses pembelajaran menggunakan modul IPA terpadu berbasis inkuiri terbimbing pada materi fotosintesis yang dikembangkan, membutuhkan waktu yang relatif lama, karena itu beberapa alat dan bahan yang digunakan sebaiknya dirangkai terlebih dahulu.

\section{DAFTAR PUSTAKA}

Depdiknas,2006.Model Pengembangan silabus Mata Pelajaran dan Rencana Pelaksanaan Pembelajaran IPA Terpadu SMP/MTs. Jakarta: Pusat kurikulum, Balitbang Depdiknas Mularsih.2007. Pembelajaran individual dengan menggunakan modul. Jakarta.Pusat sumber Belajar Universitas Taruma Negara.

Riduwan. 2012. Skala Pengukuran Variabel-variabel Penelitian. Bandung: Alfabeta

Sugiyono.2016. Metode Penelitian kuantitatif, Kualitatif, dan $R \&$ D. Bandung: Alfabeta. 